\title{
ISOLASI DAN IDENTIFIKASI JAMUR PADA CANGKANG TELUR PENYU LEKANG (Lepidochelys olivacea) GAGAL MENETAS DI PANTAI BOOM BANYUWANGI
}

\section{Isolation And Identification of Fungus From Olive Ridley (Lepidochelys olivacea) Egg Shell Which Fail to Hatch in Boom Seashore Banyuwangi}

\author{
Ratih Novita Praja ${ }^{1 *}$, Aditya Yudhana ${ }^{2}$, Wiyanto Haditanojo ${ }^{3}$ \\ ${ }^{1}$ Laboratorium Bakteriologi dan Mikologi, Departemen Mikrobiologi Veteriner, \\ ${ }^{2}$ Laboratorium Parasitologi, Departemen Parasitologi Veteriner, \\ ${ }^{3}$ Banyuwangi Sea Turtle Foundation, \\ Fakultas Kedokteran Hewan, Universitas Airlangga, \\ Kampus C Mulyorejo, Surabaya, Jawa Timur, Indonesia, 60115 \\ Telp. (031)5993016, Fax. (031)5993015 \\ *Corresponding author: ratihnovitapraja@ fkh.unair.ac.id
}

\begin{abstract}
Abstrak
Banyuwangi sebagai Kabupaten terluas di Jawa Timur memiliki kawasan konservasi dan tempat penangkaran penyu, salah satunya adalah penyu Lekang (Lepidochelys olivacea) yang sering ditemukan bertelur di kawasan pantai Boom Banyuwangi. Infeksi jamur merupakan salah satu faktor yang menyebabkan telur penyu gagal menetas, oleh karena itu perlu dilakukan penelitian untuk isolasi dan identifikasi jenis jamur yang terdapat pada cangkang telur penyu Lekang yang gagal menetas. Sampel cangkang telur penyu Lekang dengan kriteria gagal menetas diambil secara acak dari sarang. Isolasi dilakukan di kawasan penangkaran penyu di pantai Boom Banyuwangi dan identifikasi dilakukan di Laboratorium Mikrobiologi, Prodi Kedokteran Hewan, Universitas Airlangga, PSDKU Banyuwangi. Hasil penelitian menunjukkan dua jenis jamur yang teridentifikasi, yaitu Fusarium spp. dan Aspergillus spp. dari cangkang telur penyu Lekang yang gagal menetas.
\end{abstract}

Kata kunci: jamur, cangkang telur, Penyu Lekang, Pantai Boom, Banyuwangi

\begin{abstract}
Banyuwangi as the widest region in East Java has conservation area and sea turtle breeding area, one of them is Olive ridley turtle (Lepidochelys olivacea) which often found laying egg in Banyuwangi Boom seashore area. Fungal infections is one of the factors that cause sea turtle eggs fail to hatch, therefore it is necessary to conduct research for isolation and identification of fungus species which found in Olive ridley turtle egg shell that fail to hatch. Olive ridley turtle egg shell samples with criteria fail to hatch were taken randomly from the nest. The isolation was done in the sea turtle breeding area at Banyuwangi Boom seashore and identification was done in Laboratory of Microbiology, Faculty of Veterinary Medicine, Airlangga University, PSDKU Banyuwangi. The results showed two types of fungi were identified that is Fusarium spp. and Aspergillus spp. from Olive ridley turtle egg shell that fail to hatch.
\end{abstract}

Key words: fungus, egg shell, Olive ridley turtle, Boom seashore, Banyuwangi

\section{PENDAHULUAN}

Indonesia memiliki enam dari tujuh jenis penyu yang hidup di dunia dan empat jenis penyu diantaranya bisa ditemukan di Banyuwangi. Salah satu wilayah yang ditetapkan sebagai kawasan konservasi penyu di Banyuwangi adalah kawasan pantai Boom.
Penyu Lekang adalah salah satu jenis penyu yang paling banyak ditemukan di sekitar kawasan penangkaran penyu di pantai Boom. Penyu Lekang saat ini ditetapkan sebagai spesies yang terancam punah dan dimasukkan dalam daftar Appendix 1 pada Red Book Data oleh The International Union for Conservationof Nature and Natural Resource (IUCN) (Cornellius et al., 2007). 
Konservasi penyu merupakan program penting yang dilakukan untuk melindungi dan menyelamatkan populasi penyu dari berbagai ancaman, seperti; pengelolaan teknik-teknik konservasi yang tidak memadai, perdagangan telur, penangkapan penyu dan serangan mikroba Telur penyu yang berada dalam pasir sarang mengalami masa inkubasi yang panjang dan sangat rentan terhadap serangan mikroba.

Menurut Clusella dan Paladino (2007), mikroba yang mengkontaminasi telur umumnya masuk melalui pori-pori telur. Beberapa jenis jamur yang teridentifikasi pada cangkang telur penyu yang gagal menetas diantaranya Fusarium solani dan Fusarium oxysporum yang ditemukan pada sarang pasir penyu Belimbing di Kolombia (Phillott et al., 2002). F. Solani dan F. oxysporum juga ditemukan pada telur penyu Hijau, penyu Tempayan, penyu Sisik dan penyu Pipih di Pantai Timur Australia (Phillott et al., 2004). Sampai saat ini belum ada informasi dan data tentang identifikasi jamur pada cangkang telur penyu Lekang yang gagal menetas di kawasan konservasi pantai Boom.

Penelitian ini bertujuan untuk mengidentifikasi jamur yang ditemukan pada cangkang telur penyu lekang yang gagal menetas sehingga penelitian ini dapat mendukung program konservasi penyu di Banyuwangi.

\section{METODE PENELITIAN}

Penelitian ini dilaksanakan di Penangkaran penyu pantai Boom dan Laboratorium Mikrobiologi, Prodi Kedokteran Hewan, Universitas Airlangga, PSDKU Banyuwangi. Pengambilan sampel dilakukan dengan teknik Purposive sampling dan data yang diperoleh dianalisis secara deskriptif. Sampel yang digunakan adalah cangkang telur penyu Lekang (Lepidochelys olivacea) yang gagal menetas. Pengambilan sampel cangkang telur yang gagal menetas sebanyak 15 butir dari masing-masing sarang yang berbeda dan dipisahkan dari pasir yang menempel pada cangkang. Selanjutnya setiap sampel dipisahkan dalam wadah plastik steril. Isolasi jamur pada cangkang dilakukan dengan teknik penanaman secara langsung pada media SDA dan isolat diidentifikasi dengan pengamatan makroskopis dan mikroskopis. Pengamatan secara makroskopis dengan memperhatikan bentuk koloni, warna koloni dan secara mikroskopis meliputi bentuk hifa, bentuk konidia dan sporangium.

\section{HASIL DAN PEMBAHASAN}

Hasil penelitian identifikasi jamur pada cangkang telur penyu lekang yang gagal menetas di penangkaran pantai Boom, disajikan pada Tabel 1. Dapat dilihat bahwa hasil isolasi jamur dari cangkang telur penyu lekang yang gagal menetas di penangkaran pantai Boom, dari total 15 sampel ditemukan 13 positif jamur yang teridentifikasi sebagai jamur Fusarium spp. dan Aspergillus spp.

Guclu (2010) melaporkan jamur Aspergillus ini ditemukan juga pada isolasi jamur dari sarang pasir telur penyu Caretta caretta di Turki. Mo et al., (1990) dalam penelitiannya menyatakan bahwa Aspergillus spp. ditemukan dipasir sarang yang menetas, bahkan Aspergillus telah dianggap sebagai salah satu jamur bisa yang mengkontaminasi melalui udara (Phillott,2002). Aspergillus spp. juga pernah diidentifikasi dari kulit telur penyu yang berhasil menetas (Mallo et al.,2002).

Telur-telur penyu yang gagal menetas telah diketahui bahwa telur terkontaminasi oleh jamur. Jamur hadir dari dalam pasir dan menginfeksi kulit telur dan menyerang telur-telur yang sehat selama proses inkubasi di dalam sarang. Telur penyu yang telah rusak dan busuk mempengaruhi telur-telur lainnya yang berada dalam kontak langsung telur sehat sehingga untuk tingkat keberhasilan penetasan dalam sarang tersebut sangat kecil akibat dari masuknya infeksi dari jamur (Verweij dan Brandt, 2007).

Jamur dari genus Fusarium sering dilakukan isolasi dan tercatat sebagai patogen tanah yang menular pada bagian luar telur yang gagal menetas. Jamur menembus lapisan anorganik dan organik dari cangkang untuk memanfaatkan jaringan embrio sebagai sumber nutrisi (Phillott, 2002). Fusarium dapat mempengaruhi kehidupan 
penyu dengan cara persaingan dalam dan jamur berkembang dalam sarang dengan mendapatkan nutrisi dengan embrio, jamur memanfaatkan nutrisi yang diperoleh dari telur Fusarium menjadi lebih bebas menginfeksi telur (Phillott dan Parmenter, 2001).

Tabel 1. Hasil isolasi jamur dari cangkang telur Penyu Lekang (Lepidochelys olivacea) yang gagal menetas di penangkaran penyu Pantai Boom

\begin{tabular}{cccc}
\hline $\begin{array}{c}\text { Nomor } \\
\text { sampel }\end{array}$ & $\begin{array}{c}\text { Cangkang telur } \\
\text { gagal menetas }\end{array}$ & $\begin{array}{c}\text { Pertumbuhan koloni } \\
\text { jamur pada media } \\
\text { SDA }\end{array}$ & Jenis jamur \\
\hline $\mathbf{1}$ & Sarang 1 & + & Aspergillus spp. \\
$\mathbf{2}$ & Sarang 2 & + & Aspergillus spp. \\
$\mathbf{3}$ & Sarang 3 & - & - \\
$\mathbf{4}$ & Sarang 4 & + & Aspergillus spp. \\
$\mathbf{5}$ & Sarang 5 & + & Aspergillus spp. \\
$\mathbf{6}$ & Sarang 6 & + & Aspergillus spp. \\
$\mathbf{7}$ & Sarang 7 & + & Aspergillus spp. \\
$\mathbf{8}$ & Sarang 8 & - & - \\
$\mathbf{9}$ & Sarang 9 & + & Aspergillus spp. \\
$\mathbf{1 0}$ & Sarang 10 & + & Aspergillus spp. \\
$\mathbf{1 1}$ & Sarang 11 & + & Aspergillus spp. \\
$\mathbf{1 2}$ & Sarang 12 & + & Fusarium spp. \\
$\mathbf{1 3}$ & Sarang 13 & + & Aspergillus spp. \\
$\mathbf{1 4}$ & Sarang 14 & + & Aspergillus spp. \\
$\mathbf{1 5}$ & Sarang 15 & + & Fusarium spp. \\
\hline
\end{tabular}

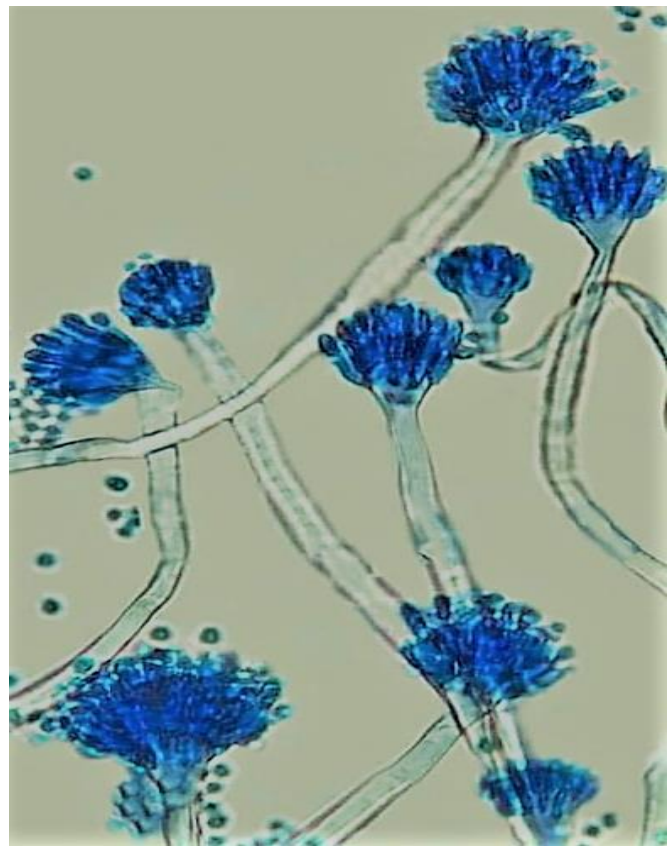

(a)

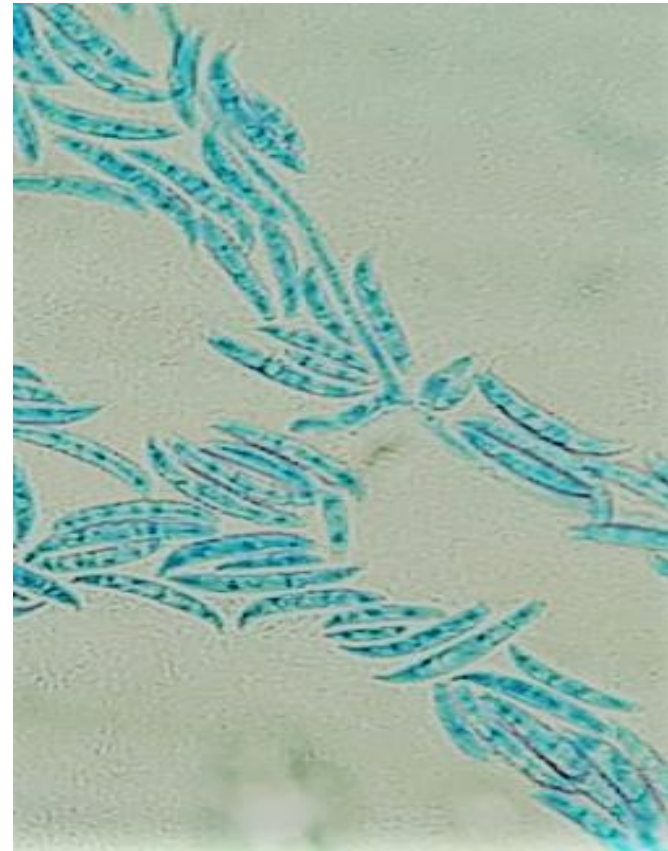

(b)

Gambar 1. Koloni mikroskopis (a) Aspergillus spp; (b) Fusarium spp

Jamur Fusarium merupakan salah satu jamur yang ditemukan pada pasir sarang telur penyu (Guclu et al., 2010; Sarmiento dan Ramirez et al., 2010). Fusarium dilaporkan bersifat sebagai parasit pada penyu terutama di bagian kepala, leher dan kulit penyu jenis Caretta caretta 
(Peters et al., 1994). Genus Fusarium ditemukan juga pada isolasi pasir sarang yang berhasil menetas, hal tersebut mengindikasikan jamur ini terdapat dalam pasir dan masuk kedalam sarang sehingga mempengaruhi inkubasi dan daya tetas telur penyu.

Menurut Phillot dan Parmenter (2001) bahwa jamur hadir dalam pasir sarang telur penyu. Fusarium merupakan jamur patogen yang pernah diisolasi dari penyu hijau yang menunjukkan gejala klinis penyakit saluran nafas (Glazebrook et al., 1993). Jamur ini menyebabkan penyakit atau mengganggu fungsi sel normal karena racun yang dihasilkan atau memproduksi enzim yang dapat mengganggu atau merusak sel-sel dalam telur (Fang et al., 2005).

\section{KESIMPULAN}

Jamur yang berhasil diisolasi dari cangkang telur penyu Lekang (Lepidochelys olivacea) yang gagal menetas di pantai Boom Banyuwangi teridentifikasi dari jenis Fusarium spp. dan Aspergillus spp. Dari total 15 sampel yang diteliti ditemukan 13 sampel positif jamur yang teridentifikasi sebagai jamur Fusarium spp. dan Aspergillus spp.

\section{UCAPAN TERIMA KASIH}

Peneliti mengucapkan banyak terima kasih kepada Rektor, Dekan Fakultas Kedokteran Hewan dan Ketua Program Studi Kedokteran Hewan Universitas Airlangga PSDKU Banyuwangi atas diberikannya kesempatan untuk melaksanakan penelitian ini dan juga kepada pihak Banyuwangi Sea Turtle Foundation atas segala bantuan dan dukungan dalam penelitian sehingga penelitian ini dapat terselesaikan dengan baik.

\section{DAFTAR PUSTAKA}

Clusella, T.S., and F.V. Paladino. 2007. Microenvironment of Olive Ridley Turtle Nest Deposited During an Aggregated Nesting Event. J Zool, 272:367-376.
Cornelius, S.E., R. Arauz., J. Fretey., M.H. Godfrey., R. Marquez., and K. Shanker. 2007. Effect of and based harvest of Lepidochelys. In: Plotkin, P.T. (Ed.). TheBiology and Conservation of Ridley SeaTurtles. Baltimore: Johns Hopkins University Press, pp. 231-251.

Fang, Z., O. Zyihun, L. Hu, X. Wang, H. Zheng, X. Lin. 2005. Culturable air borne fungi in outdoor environments in Beijing, China. Sci. Total Environ, 350: 47-58.

Glazebrook, J.S., R.S.F. Campbell, T. Thomas. 1993. Studies on an ulcerative stomatitis obstructive rhinitis-pneumonia disease complex in hatchling juvenile sea turtles Chelonia mydas and Caretta caretta. Dis. Aquatic Organisms, 16: 133-147.

Guclu, O. 2010. Mycroflora Identified From Loggerhead Turtle (Caretta caretta) egg shells and nest sand at Fethiye Beach, Turkey. African Journal of Microbiology Research, 4(5): 408-413.

Mallo, K., A.H. Craig, A.L. Gregory, G.P. Mark. 2002. Pharmacokinetics of fluconazole in loggerhead sea turtles (caretta caretta) after single intravenous and subcutaneous injections, and multiple subcutaneous injections. J. Zool. Wildlife Med, 33(1): 2935.

Mo, C.L., I. Salas, M. Caballero. 1990. Are fungi and bacteria responsible for olive ridley's egg loss? In proceedings of the 10th annual workshop on sea turtle biology and conservation. Richardson et al. (eds) NQAA Technical Memorandum NMFS-SEFC-278: 249-252.

Peters, A., K.J.F. Verhoeven, H. Strijbosch. 1994. Hatching and emergence in the Turkish Mediterranean loggerhead turtle, Caretta caretta: natural causes for egg and hatchling failure. Ecol, 60: 946-955. 
Phillott, A.D., and C.J. Parmenter. 2001. Influence of diminished respiratory surface area on survival of sea turtle embryos. Journal Zoology, 289:317-321.

Phillott, A.D., C.J. Parmenter., C.J. Limpus., and K.M. Harrower. 2002. Mycobiota as acute dan chronic cloacal contaminants of female sea turtles. Journal Zoology, 50:687-695.

Phillott, A.D., C.J. Parmenter, C.J. Limpus. 2004. Occurrence of mycobiota in eastern Australian sea turtle nests. Memoirs of the Queensland Museum, 49(2): 701-703.
Sarmiento-Ramirez, E. Abella, M.P. Martın, M.T. Telleria, L.F. lopezJurado, A. Marco., and J. Dieguezuribeondo. 2010. Fusarium solani is responsible for mass mortalities in nests of loggerhead sea turtle, Caretta caretta, in Boavista, Cape Verde. FEMS Microbiol Lett, 312:192-200.

Verweij, P.E., Brandt, M.E. 2007. Aspergillus Fusarium, and other opportunitistic moniliaceous fungi. In : Murray et al. (eds). Manual of Clinical Microbiology. Ch. 121. 9th ed. ASM Press. Washington DC. 18021838. 